\title{
MASALAH KEBUTUHAN SEKSUAL PADA PASIEN GAGAL GINJAL KRONIK YANG MENJALANI TERAPI HAEMODIALISA
}

\author{
Sri Haryani, Misniarti \\ Politeknik Kesehatan Kementerian Kesehatan Bengkulu, Jurusan Keperawatan, \\ Jalan Indragiri Nomor 03 Padang Harapan Kota Bengkulu \\ sri.ani37@gmail.com
}

\begin{abstract}
Sexual problems are most important problem in CRF patients undergoing hemodialysis. Feelings of shame and guilt for having sexual problems can cause a fear that the problem will recur and eventually make a person avoid a sexual situation. Haemodialisa interview results in patients admitted in hospitals Curup decreased in terms of sexuality, quickly tired during intercourse, fatigue, and less passionate. This study aimed to obtain sexual needs of patients with chronic renal failure undergoing Haemodialisa. This study uses qualitative research with phenomenological approach. The result showed that most informants are still sexual activity, four informants told decline and experiencing problems while two informants have no problems and all the informants complain quickly limp, tired and lackluster while undergoing sexual activity. 5 informants said there are problems since suffering a disease with chronic renal failure and one informant said that because of the age factor. This study is recommended to do health education to couples, families and communities to always provide support to patients in order to live life with optimism.
\end{abstract}

Keywords: sexual needs, patients with chronic renal failure, hemodialysis therapy

\begin{abstract}
Abstrak: Masalah seksual merupakan masalah yang paling utama pada pasien GGK yang menjalani haemodialisis. Perasaan malu dan bersalah karena mengalami masalah seksual dapat menyebabkan ketakutan bahwa masalah akan terulang dan akhirnya membuat seseorang menghindari situasi seksual. Hasil wawancara pada pasien haemodialisa di RSUD Curup mengaku mengalami penurunan dalam hal seksualitas, cepat lelah saat berhubungan, lemas, dan kurang bergairah. Penelitian ini bertujuan untuk memperoleh gambaran kebutuhan seksual pasien gagal ginjal kronik yang menjalani haemodialisa. Penelitian ini menggunakan metode penelitian kualitatif dengan pendekatan fenomenologi. Hasil penelitian didapatkan bahwa kebanyakan informan masih melakukan aktifitas seksual, 4 informan mengatakan terjadi penurunan dan mengalami masalah sedangkan 2 informan tidak memiliki masalah dan 6 informan mengeluh cepat lemas, cepat lelah dan kurang bergairah saat menjalani aktivitas seksual, serta 5 informan mengatakan permasalahan ini ada sejak mengalami penyakit gagal ginjal kronik dan 1 informan mengatakan karena faktor usia. Penelitian ini direkomendasikan untuk dilakukannya pendidikan kesehatan pada pasangan, keluarga dan masyarakat untuk selalu memberikan dukungan pada pasien agar dapat menjalani hidup dengan optimis.
\end{abstract}

Kata Kunci: Kebutuhan seksual, pasien GGK, terapi haemodialisa.

Menurut Rodericketal (2008), bahwa hampir setengah dari penduduk yang memiliki penyakit ginjal tidak mengetahui bahwa ada yang salah dengan ginjalnya. Bila pasien telah mengalami GGK stadium berat, untuk mempertahankan hidupnya diperlukan terapi sementara berupa cuci darah (haemodialisa) (Sinaga, 2007). Hal serupa disampaikan Roesli (2006), bahwa sistem dialisa bagi penderita merupakan keadaan ketergantung- an pada mesin dialisa seumur hidupnya serta penyesuaian diri terhadap kondisi sakit yang mengakibatkan terjadinya perubahan dalam kehidupan pasien.

Survey yang dilakukan oleh Perhimpunan Nefrologi Indonesia Pernefri (2009), prevalensi penyakit gagal ginjal kronis di Indonesia, paling banyak terjadi pada kelompok umur $\geq 75$ tahun $(0,6 \%)$. Berdasarkan jenis kelamin laki-laki $(0,3 \%)$ lebih 
tinggi dari perempuan $(0,2 \%)$, prevalensi lebih tinggi pada masyarakat perdesaan $(0,3 \%)$, tidak bersekolah $(0,4 \%)$, pekerjaan wiraswasta, petani /nelayan /buruh $(0,3 \%)$, dan kuintil indeks kepemilikan terbawah dan menengah bawah masing-masing 0,3\% (Riskesdas, 2013).

Berdasarkan data dari Renal Registry prevalensi gagal ginjal kronik di Indonesia pada tahun 2012 sekitar $12,5 \%$ berarti sekitar 18 juta orang dewasa di Indonesia menderita penyakit gagal ginjal kronik. Tahun 2011 di Indonesia terdapat $153,53 \%$ pasien yang menjalani HD dan pada tahun 2012 terjadi peningkatan sebesar $42,68 \%$ pasien yang menjalani HD, sedangkan akhir tahun 2012 terdapat 244 unit haemodialisis di Indonesia. Di Bengkulu terdapat 0,3\% kasus GGK (Riskesdas, 2013) dan berdasarkan laporan Dinas Kesehatan Kota Curup kasus gagal ginjal kronik sebanyak 2,2\% dan data dari Rumah Sakit Umum Daerah (RSUD) Curup prevalensi penyakit gagal ginjal kronik yang menjalani haemodialisa berjumlah 7,8\%.

Perasaan malu dan bersalah karena mengalami masalah seksual dapat menyebabkan ketakutan bahwa masalah akan terulang dan akhirnya membuat seseorang menghindari situasi seksual (Aguslemi, 2012). Pria dengan GGK akan mengalami penurunan libido, disfungsi ereksi dan kesulitan mencapai orgasme. Wanita dengan GGK mengalami kesulitan dengan gairah seksual, disminore, keterlambatan perkembangan seksual, gangguan lubrikasi vagina, dyspareunia, dan kesulitan mencapai orgasme (Nephrol, 2010). Menurut penelitian Irawati (2011) yang menunjukkan bahwa frekuensi hubungan seksual partisipan mengalami penurunan yang ditandai dengan tidak adanya aktivitas seksual atauaktivitas seksual yang jarang.

Hasil wawancara yang dilakukan di Rumah Sakit Umum Daerah (RSUD) Curup tanggal 5 Januari 2015 terhadap 9 orang pasien haemodialisa, 7 orang (5 pria dan2 wanita) mengalami penurunan fungsi seksual (disfungsi seksual). Mereka mengalami penurunan dalam hal seksualitas, cepat lelah saat berhubungan, lemas, dan kurang bergairah. Tetapi terdapat 2 orang pria dan wanita mengatakan tidak ada masalah dengan pemenuhan kebutuhan seksualitas.

Berdasarkan fenomenologi diatas, penelitian ini bertujuan untuk memperoleh gambaran kebutuhan seksual pasien gagal ginjal kronik yang menjalani haemodialisa.

\section{BAHAN DAN CARA KERJA}

Penelitian ini mengunakan metode penelitian kualitatif dengan pendekatan fenomenologi. Pengumpulan data dengan menggunakan teknik wawancara mendalam (indepth interview) menggunakan pertanyaan terbuka yang nantinya akan di kembangkan sehingga lebih mendalam. Wawancara yang digunakan adalah wawancara tidak terstruktur dan menggunakan pedoman wawacara dan hasil wawancara akan direkam menggunakan tape record-er. Pengambilan sampel dengan consecutive sampling. Instrumen penelitian dengan menggunakan skala Hill-Bone Scaleyang digunakan untuk menilai kepatuhan pasien dalam minum obat antihipertensi. Instrumen telah dilakukan uji validitas dan reliabilitas. Hasil penelitian didapatkan empat tema yaitu: Aktivitas seksual pasien gagal ginjal kronik degan terapi haemodialisa, respon seksual pasien gagal ginjal kronik dengan terapi haemodialisa, permasalahan seksual pasien gagal ginjal kronik dengan terapi haemodialisa, dan penyebab terjadinya masalah seksual pada pasien gagal ginjal kronik dengan terapi haemodialisa.

\section{HASIL}

\section{Karakteristik}

Tabel 1. Gambaran karakteristik informan yang sedang menjalani pengobatan hemodialisa

\begin{tabular}{|c|c|c|}
\hline Inisial & Usia & Alamat \\
\hline Bpk.H & 45 tahun & $\begin{array}{l}\text { Desa Dusun Curup Kabupaten } \\
\text { Rejang Lebong }\end{array}$ \\
\hline Bpk.A & 48 tahun & $\begin{array}{l}\text { Desa Talang Rimbo Curup } \\
\text { Kabupaten Rejang }\end{array}$ \\
\hline Bpk.A & 39 tahun & Kabupaten Kepahiang \\
\hline Bpk.B & 50 tahun & Kabupaten Lebong \\
\hline Bpk.A & 53 tahun & $\begin{array}{l}\text { Desa Talang Rimbo Kabupaten } \\
\text { Rejang }\end{array}$ \\
\hline Bpk.S & 29 tahun & Kabupaten Lebong \\
\hline
\end{tabular}

Analisa Tema 
Aktivitas seksual pasien gagal ginjal kronik degan terapi haemodialisa

Berdasarkan hasil wawancara terhadap informan mengenai kebutuhan seksual pasien haemodialisa tentang aktivitas seksual. Adapun hasil wawancara sebagai berikut:

"Tidak, dibilang kita tidak gek maaf ngomong tu nyo tu ibaratnyo tu nafsu tu nggak ada,gak ada minat istilahnyo, dari bapaknyo(kata istri). masih juga ngeja-lani (aktivitas seksual)tapi idak cak dulu,lemes badan tu litak. Sebelum cuci darah dalam sebulan tu sekali (menja-lani aktivitas seksual) setelah cuci darah katakan gak ada salah juga,kadang idak dalam sebulan" (RI, 45 th).

"Kalo kito dikato dak do masalah lah tentang itu, cuma dak seperti biaso secaro seksualnyo, memang keinganan ado terus, kalo dulu tu seminggu sekali, kalo sekarang kalo seminggu kadang malas, bisa jadi pengaruh itu dari penyakit (gagal ginjal), kalo dulu maaf kito ngomong sebulan tu 30 kali, kalo sekarang ko setengah bulan sekali, rasonyo dikarnokan usia,tapi usia idak pulo, intinyo karno penyakit(gagal gin-jal), umur 48, yo memang agak lemes-le-mes dikit tubuh kito, cepet capek, perbedaan sudah jelas mbak" (R2,48 th).

"Alhamdulillah (masih menjalani aktivi-tas seksual), kalo untuk sekarang ini belum,tapi karno kito sakit kan iyo kito idak seperti sebelum sakit itu terlalu muncak kan,kalo sakit ni banyak mikir, Yo agak bekurang ny itu, karno waktu sholat itu meningkat karno sebelum sakit kan sholat tu masih jarang, yo kalau segi seks nyo itu kalo HB masih normal frekuensi (frekuensi beraktivitas seksual) dak nurun, kalo HB rendah iyo. maaf dek yo, sampe seminggu paling nggajak tu 5 kali, kalo sekarang paling 2 kali sampai 3 kali, terkadang lemes karno sakit, terkadang mikir kan kito mau sho lat"(R3,39 th).

"Masih (menjalani aktivitas seksual), jauh bedanyo istilahnyo idak normal lagi, lemas, maaf ngomong yo istilahnyo dak ndak hidup lagi tu nah,kalo dulu sebelum sakit 3 kali la (beraktivitas seksual), kalo kini seminggu seka-li"(R4,50 th).

"Awal awalnyo dulu iyo,sekarang udah idak mampu lagi, dakdo kemampuan. Dulu tu seminggu 1 apa 2 kali, kalo sekarang idak pernah." (R5, 53 th $)$.
"Masih (menjalani aktivitas seksual) perubahan banyak, lemes, badan kita itu berisi (sembeb),yang jelasnya berkurang, jadi jarang (beraktivitas seksual), sama nggak bertahan lama.Sebelum cuci darah seminggu 1-3 kali, kalo sekarang paling 1 kali, kadang tu idak nian"(R6,29 th).

Respon seksual pasien gagal ginjal kronik dengan terapi haemodialisa

Hasil wawancara dengan informan mengenai respon seksual yaitu respon berupa keinginan atau minat untuk menjalani hubungan seksual dengan adanya penyakit gagal ginjal kronik dan menjalani terapi haemodialisa yang informan alami, sebagian besar informan (4 orang) mengatakan terjadi penurunan dan mengalami permasalahan pada respon seksual, sedangkan 2 orang lagi mengatakan respon seksual nya masih baik.

"Menurun (respon seksual), ibarat tu nafsu tu gak ada,gak ada minat lagi" (R1, 45 tahun).

"Kurang (respon seksual), biaso ado spontan nafsu, iyo penurunan ado (minat untuk beraktivitas seksual)" (R2, 48 th).

"Alhamdulillah (respon seksual baik). masih, ado penurunan dikit tapi” (R3, 39 th).

"Masih (respon seksual masih bagus), keinganan masih kadang-kadang tu nor-mal jugo,mungkin waktu sehatnyo. Ado waktu normalnyo kito berhubungan (R4, 50 th).

"Saya itu pasif mbak, minat idak ado, keinginan dak ado, pasif jadinyo”(R5, 53 th).

"Nggak ada (respon seksual tidak ada masalah) kalo keinginan masih, penu-runan minat iya jelas" (R6, 29 th).

Permasalahan seksual pasien gagal ginjal kronik dengan terapi haemodialisa

Berdasarkan hasil wawancara terhadap informan tentang permasalahan seksual pasien gagal ginjal kronik dengan terapi haemodialisa mayoritas informan mengatakan adanya permasalahan dalam aktivitas seksual mereka sejak menjalani haemodialisa. Adapun hasil wawancara sebagai berikut:

"Idak ado nafsu lagi, saat berhubungan cepat lemas, mulai dari awal cuci darah, karno dari awal udah lemes nian, hubungan 
samo ibuk biaso bae, harap maklum pulo" (R1, 45 th).

"Agak lemes-lemes dikit tubuh kito, cepet capek idak seperti itu kito tu dulu termasuk garang lah. Mulai kito sakit tu mbak (penurunan aktifitas seksual) sakit dirumah bae duo bulan dirawat, belum cuci darah belum tau penyakt ini tadi,kiro kito maag udah duo bulan di rawat di rumah,udah duo bulan idak jugo,akhirnyo di bawak ke rumah sakit, disitulah di check up baru tau gagal ginjal, baru disuruh cuci darah, penu-runan seksual sejak 2 bulan sakit sebelum tau gagal ginjal tu, sudah cuci darah jugo masih. Baik-baik ajo, kadang yo maklumlah ibuknyo masih mudo, kadang dio minta samo kito kan, nah kito "ai litak eh malas", tapi untung ngerti ibuknyo" (R2, 48 th).

"Boleh dikatakan nurun itu lah, (fre-kuensi berhubungan), malah sebelum cuci darah itu waktu sakit (gagal ginjal) itu la nurun (aktivitas seksual)belum cuci darah tapi la tau gagal ginjal, udah cuci darah mulai stabil lagi. alhamdulillah baik-baik ajo istri sangat mengerti" (R3, 39 th).

"Lemas, kurang ado rangsangan, sejak awal cuci darah sejak awal sakit gagal ginjal, Idak (tidak ada masalah dengan istri)" (R4, 50 th).

"Sekarang udah idak mampu lagi, dakdo kemampuan, pasif, 2-3 bulan awal cuci darah masih, setelah itu idak lagi (beraktivitas seksual), Baik-baik ajo (hu-bungan dengan istri" (R5, 53 th).

"Lemes, kurang bertahanlamo, samo penurunan minat, sejak setahun cuci darah, iyo baik baik ajo (hubungan dengan istri)" (R6, 29 th).

Penyebab terjadinya masalah seksual pada pasien gagal ginjal kronik dengan terapi haemodialisa

Berdasarkan hasil wawancara terhadap informan mengenai pendapat informan terhadap penyebab terjadinya masalah seksual pada pasien gagal ginjal kronik dengan terapi haemodialisa mayoritas informan mengatakan mereka mulai mengalami permasakan seksual sejak terdiagnosa gagal ginjal kronik dan menjalani terapi haemodialisa. Adapun hasil wawancara sebagai berikut:

"Pertama tuh, kita tuh ibarat tu, bukan ibarat badan kito tu lesu dak do gairah samo sekali. Nggak ada, biarin ajo,karno memang kondisinyo cak itu” (R1, 45 th).

"Iyo karno penyakit (gagal ginjal). Dak ado mbak, iyo biarkan ajo karno keada-annyo seperti itu” (R2, 48 th).

"Bisa jadi karno usia (usia $R=39$ th). Kalo Kito punya itukan dari kesehatan kan ,makan,minum madu, makan telur putih, pokoknya gizi harus dijaga dek" (R3, 39 th).

"Yo karno cuci darah, biarkan ajo karno kadang kadang kan normal" (R4, 50 th).

"Karno cuci darah,walaupun diabetes dulu masih (beraktivitas seksual) 2-3 bulan cuci darah masih (beraktifitas seksual), setelah itu idak lagi. Dak ado biarin ajo” (R5, 53 th).

"Ya itu karno sakit ginjal itu, nggak ada dibiarin ajo" (R6. 29 th).

\section{PEMBAHASAN}

\section{Aktivitas seksual}

Aktivitas seksual pasien diidentifikasikan dari keinginan pasien untuk melakukan hubungan seksual. Pada penelitian ini didapatkan bahwa seluruh informan mengalami perubahan dan penurunan aktivitas seksual. Perubahan yang dialami diantaranya merasa cepat lemas dan tidak bertahan lama saat menjalani aktivitas seksual, kurang bergairah, adanya penurunan minat untuk melakukan aktivitas seksual. Hasil ini sejalan dengan penelitian yang dilakukan Arslan dan Ege (2009) yang mengemukakan bahwa pasien penyakit ginjal kronik yang menjalani haemodialisa mengalami penurunan keinginan dalam berhubungan seksual. Hasil penelitian yang dilakukan oleh Soykan (2004) diTurki yang melibatkan 43 orang pasien haemodialisa yang terdiri dari 25 orang laki-laki dan 18 orang perempuan, menemukan bahwa $40 \%$ informan tidak melakukan aktivitas seksual.

Pendapat tersebut sesuai dengan Doss, dkk (2012) yang menyatakan bahwa $60 \%$ responden memiliki dorongan seksual sangat lemah, sedangkan $6 \%$ mengatakan dorongan seksual sangat kuat. Gangguan seksual pada penyakit ginjal dengan haemodialisa hanya dialami oleh pasien wanita dan usia kurang dari 60 tahun (Bass et al. 2012). Telah diketahui terkait gagal ginjal kronis 
dengan impotensi dan hilangnya libido di laki-laki dan bagi banyak wanita, infertilitas dan ketidakteraturan menstruasi (Lessan dkk, 2011).

Ini sesuai dengan teori motivasi yang paling dikenal mungkin adalah Teori Hierarki Kebutuhan Maslow yang berpendapat bahwa pada diri tiap orang terdapat hierarki lima kebutuhan yaitu diantaranya kebutuhan fisik: makanan, minuman, tempat tinggal, kepuasan seksual, dan kebutuhan fisik lain. Bagi maslow, cinta menyangkut suatu hubungan sehat dan penuh kasih mesra antara dua orang, termasuk sikap saling percaya dalam hubungan yang sejati tidak akan ada rasa takut, sedangkan berbagai bentuk pertahanan pun akan runtuh. Seringkali cinta menjadi rusak jika salah satu pihak merasa takut kalau kelemahan-kelemahannya serta kesalahan-kesalahannya terungkap (Globe, 2010)

\section{Respon seksual}

Pada penelitian ini didapatkan hasil bahwa sebagian informan mengalami gangguan dengan respon seksualnya yaitu pada (R1,R2,R5). Berbagai reaksi yang diungkapkan oleh informan karena adanya penurunan seksual setelah menjalani haemodialisa seperti perasaan malu, dan kurangnya minat dari tim medis dalam merespon keluhan pasien, terjadi depresi primer atau depresi subklinis serta lamanya dari penyakit kronis (Arslan, dkk, 2002). Sesuai dengan Irawati (2010) yang menyatakan bahwa terjadi penurunan hubungan seksual, perubahan keinginan untuk melakukan hubungan seksual serta kepuasan yang sulit dicapai sesuai dengan keinginan partisipan. Pada partisipan laki-laki terjadi disfungsi seksual yaitu disfungsi ereksi dan ejakulasi dini. Permasalahn ini terjadi karena adanya perubahan fisik dan terjadinya disfungsi ginjal yang sudah menurun serta adanya perubahan psikologis dari partisipan.

Sebagian informan mengaku masih memiliki respon seksual yang baik walaupun kualitas untuk melakukan hubungan sek sudah berkurang (R3, R4, R6). Dua pertiga dari pasien yang mendapat terapi HD tidak pernah kembali pada aktifitas atau pekerjaan seperti sedia kala. Dengan demikian pasien akan mengalami kehilangan pekerjaan, penghasilan, kebebasan, harapan umur panjang, fungsi seksual sehingga dapat mengakibatkan kehilangan harga diri dan identitas gender. Rasa kehilangan ini akan mengakibatkan efek kemarahan yang akhirnya timbul suatu keadaan depresi sekunder sebagai akibat dari penyakit sistemik yang mendahuluinya (Friedman, 1999).

HD dapat memperpanjang usia tanpa batas yang jelas. Pasien tetap akan mengalami sejumlah permasalahan dan komplikasi. Pada masalah fisik akan terjadi hipotensi, hipertensi, kram, demam, kedinginan, infeksi, gangguan, cardio pulmoner, anemia, penyakit tulang, masalah kardiovaskuler, toksisitas alumunium, hiperkalemia, perdarahan, hiponatremia dan hipernatremia, emboli udara, pruritus, mual, muntah. Sedangkan pada masalah psikis terjadi stres, depresi, perilaku tidak kooperatif, perubahan kepribadian dan bunuh diri (Smeltzer dan Bare, 2004).

\section{Permasalahan seksual}

Pada penelitian ini didapatkan bahwa hampir seluruh informan (6 informan) mengalami permasalahan seksual yaitu perasaan lemas saat menjalani aktivitas seksual, cepat merasa lelah, kurang bergairah, dan tidak bertahan lama saat menjalani aktivitas seksual. Masalah fisik yang lain yang sering dikeluhkan pasien adalah gangguan seksual. Sesuai dengan Kastrouni et al, (2010) bahwa masalah seksual adalah masalah yang paling utama pada pasien GGT yang menjalani haemodialisis di Yunani. Gangguan ginjal akan mempengaruhi penampilan seksual baik pada laki-laki maupun pada wanita. Hal ini disebabkan pasien mengalami perubahan hormonal akibat uremia. Selain perubahan hormonal, efek obat juga berperan dalam gangguan seksual ini. Obat yang diberikan pada pasien hemodialisis dapat menyebabkan disfungsi seksual (Leung, 2003). 
Hal ini didukung oleh hasil penelitian Nurmawati (2011) yang menyebutkan bahwa pasien yang menjalani hemodialisis mengalami masalah dalam hubungan seksual dengan pasangannya. Adanya perubahan seksualitas pada pasien gagal ginjal dengan hemodilisa, dimana perubahan tersebut termasuk perubahan yang signifikan yaitu terjadinya disfungsi ereksi (DE) dan ejakulasi pada pria, penurunan kepuasan seksual, ganguan hasrat yang sering dialami baik pada pasien pria maupun wanita (Aslan et al, 2003 dan Rosas et al, 2010).

Orang dengan penyakit ginjal kronis (CKD) memiliki beban tinggi dan mengalami gejala kualitas hidup rendah dari pada populasi umum. Orang dengan CKD sering melaporkan kelelahan, anoreksia, nyeri, gangguan tidur, rasa gatal dan gelisah. Depresi dan disfungsi seksual mungkin juga umum di CKD, meskipun pertanyaan tentang diagnosis dan pengobatan yang optimal tetap tidak terjawab. Orang dengan penyakit ginjal mengidentifikasi gaya hidup dan dampak CKD pada keluarga dan psikososial mendukung sebagai prioritas utama dan gejala seperti disfungsi seksual dan tekanan psikologis parah (Vecchio, 2012).

Pada klien dengan penyakit ginjal kronik akhir dengan haemodialisa kronis $\mathrm{u}$ mumnya mendapatkan terapi antidepresan yang dapat menurunkan libido dan menunda orgasme pada wanita, sedangkan pada lakilaki akan menurunkan ereksi dan ejakulasi (Marques, et al, 2006; Diaz, Ferrer dan Cascales, 2006 dalam Farida, 2010).

\section{Penyebab masalah seksual}

Pada penelitian ini didapatkan hasil 5 orang informan mengatakan permasalahan seksual yang dialami dikarenakan penyakit gagal ginjal kronik yang diderita. Hal tersebut disimpulkan oleh informan karena sebelum menderita gagal ginjal kronik dan saat menjalani terapi haemodialisa informan tidak mengalami permasalahan-permasalahan seksual dan masih rutin melakukan aktivitas seksual. Arslan, dkk (2002) menyatakan bahwa kurangnya minat seksual dise- babkan oleh kelelahan kronis, kecemasan dan penurunan harga diri, terutama pada pasien yang menjalani haemodialisa tiga kali seminggu dan juga faktor usia antara 40-60 tahun. Setelah dilakukan haemodialisis pasien merasa lelah, sakit kepala, keringat dingin, kram, dan tidak buang air seni. Hal ini terjadi karena tekanan darah menurun dan sel darah merah pecah. Pengaruh lain bersifat kejiwaan dimana pasien menjadi tidak bisa mandiri dan bergantung pada mesin haemodialisis, petugas dan keluarga.

Hubungan secara medis, psikologis, dan faktor sosial, baik dalam isolasi tetapi umumnya lebih, dalam kombinasi, dapat berkontribusi untuk perubahan dalam keinginan dan fungsi seksual bagi orangorang dengan penyakit ginjal kronis (CKD). Hidup dengan penyakit kronis seperti penyakit ginjal dan melakukan pengobatannya dapat memakan waktu danmelelahkan, terutama jika pasien bekerja dalam waktu lama dan memiliki tanggung jawab terhadap keluarga. Hal ini tidak mengherankan bahwa dengan tuntutan tambahan dialisis atau perawatan lain, pasien mungkin kadangkadang merasa lelah dan depresi. Hal ini sulit untuk merasa tertarik pada seks jika pasien lelah atau tidak enak badan.

Yuwono (2000) (dalam Butar-butar, 2013) mengatakan bahwa faktor-faktor yang mempengaruhi kualitas hidup pasien gagal ginjal adalah umur, jenis kelamin, etiologi gagal ginjal, cara terapi pengganti, status nutrisi dan kondisi kormorid.Berbeda dengan pendapat Yanti (2011) bahwa lama menjalani hemodialisis tidak berhubungan secara signifikan dengan depresi, ini mungkin terjadi pada pasien yang masih dengan usia muda (dibawah 50 tahun).

Permasalahan seksual yang dialami oleh informan dengan haemodialisa ini disebabkan oleh adanya perubahan fisik, psikologis, ekonomi dan spiritualnya, terutama untuk pasien yang baru menjalani haemodialisa, tetapi untuk pasien yang telah lama mereka akan mulai dapat menyesuaikan diri kondisi tersebut (Farida, 2010). Selain faktor tersebut, faktor pendidikan 
akan sangat berperan dalam menentukan kualitas hidup informan dengan haemodialisa. Dengan kualitas hidup yang baik maka informan akan dapat menjalani kehidupan dengan baik terutama dalam menjalani aktivitas seksual sesuai dengan keadaan fisiknya (Ayyubi dkk, 2013).

\section{KESIMPULAN}

Hasil penelitian menunjukkan bahwa, meskipun informan berada dalam kondisi yang menderita dan tidak berdaya dengan keadaan penyaktinya tetapi tetap bertahan dengan adanya dorongan, pengertian dan

\section{DAFTAR RUJUKAN}

Bass, Adam., Sofia B Ahmed., Scott Klarenbach., Bruce Culleton., Brenda R Hemmelgarn., and Braden Manns. The impact of nocturnal hemodialysis on sexual function.http://www.biomedcentral.com/14712369/13/67

Aguslemi, M. Farid. EdisiJanuari. 2012. DialifeBuletinInformasiKesehatanGinjal. Jakarta: Yayasanginjaldiatrans.

Aslan et al, 2003 dan Rosas et al, 2010. http://digilib.stikesmuhgombong.ac.id/files/dis k1/29/jtstikesmuhgo-gdl-nugrohofaj-1408-1babi.pdf.

Butar-Butar, Aguswina dan Cholina Trisa Siregar. Karakteristik Pasien Dan Kualitas Hidup Pasien Gagal Ginjal Kronik Yang Menjalani Terapi Hemodialisa. Tesis Fakultas Keperawatan, Universitas Sumatera Utara.

Doss, F., \& Polaschek, N. (2012). Assessing sexual dysfunction in people living on dialysis in a New Zealand renal service. Renal Society of Australasia Journal, 8(3), 104-108.

Elvira, Sylvia. 2006. Isfungsi seksual pada perempuan. Jakarta: Balai Penerbit Fakultas Kedokteran Universitas Indonesia.

Farida, Anna. 2010. Pengalaman klien haemodialisa terhadap kualitas hidup dalam konteks asuhan keperawatan di RSUP Fatmawati Jakarta. Tesis FKUI publikasi.

Friedman,M dkk. (1999). Family Nursing Research, Theory and Practice

Hidayat, Aziz alimul. 2006. PengantarKebutuhanDasarManusia. Jakarta: SalembaMedika

Irawati, Dian. 2011. StudiFenomenologi: Pengalaman difungsi seksual pasien penyakit motivasi yang diberikan oleh istri, anak dan anggota keluarga lainnya. Aplikasi dari sebuah nilai yang dianut oleh informan membuat hidup menjadi lebih bermakna dengan adanya keyakinan bahwa keadaan sakit yang sedang dialami sekarang sematamata datang dari Allah dan akan disembuhkan oleh Allah juga. Pengertian dari pasangan sangat dibutuhkan oleh informan, sebab dengan usia yang masih muda dan keinginan seksual masih sangat kuat, sehingga kebutuhan seksual yang membara dapat dialihkan dengan kegiatan lain yang lebih positif.

ginjal kronik tahap akhir yang menjalani haemodialisa di RumahSakit Islam Jakarta. Diunduh tanggal 15 Oktober 2014 arihttp:// digital_ 20280645_ T Diana Irawati Haemodialisa.PDF (Secured).

Kastrouni M, Saratopoulou E, Aperis G, Alivanis P. 2010. Quality of life of greek patient with end stage renal diseases undergoing hemodialysis.Journal of renal care.

Lessan, Mahboob .,Pezeshkiland Shirin Ghazizadeh. 2011. Sexual and Reproductive Function in Chronic Kidney Disease and Effect of Kidney Transplantatiol. Nephrology Research Center, Imam Khomeini Hospital, Tehran University of Medical Sciences, 2 Obstetrics and Gynecology Department, Tehran University of Medical Sciences, Iran 2011 www.intechopen.com

Nephrol, Clin J. 2010. American Society Of Nephrology

RekamMedik RSUD Curup. 2014. Data PasienHaemodialisa.

Riset Kesehatan Dasar (RISKESDAS). 2013. Badan Penelitian \& Pengembangan Kementrian Kesehatan Republik Indonesia.

Vecchio, Mariacristina ., Suetonia C. Palmer., Marcello Tonelli., David W. Johnson4 and Giovanni F.M. Strippoli. Depression and sexual dysfunction in chronic kidney disease: a narrative review of the evidence in areas of significant unmet need. Oxford JournalsMedicine \& Health Nephrology Dialysis Transplantation Volume 27,Issue 9. 2014.Kidney Health Australia. 